\title{
Cultivable bacterial diversity associated with bromeliad roots from ironstone outcrops in central Brazil
}

\author{
T. F. C. Viana ${ }^{a, b}$ (D), A. P. S. Campelo ${ }^{a, b}$ (D), J. I. Baldanic (D), P. I. Fernandes-Júnior ${ }^{\text {(D), }}$ \\ V. L. D. Baldanic (D), W. M. Silva (D), G. M. Paggi ${ }^{a, b, f}$ (D) and M. S. Brasilb,f* (D)
}

aPrograma de Pós-graduação em Biologia Vegetal, Instituto de Biociências, Universidade Federal de Mato Grosso do Sul UFMS, Av. Costa e Silva, s/n, Bairro Universitário, CEP 79070-900, Campo Grande, MS, Brasil

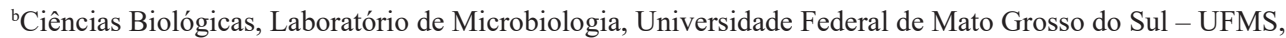
Campus do Pantanal, Av. Rio Branco, 1.270, Bairro Universitário, CEP 79304-902, Corumbá, MS, Brasil

${ }^{c}$ Embrapa Agrobiologia, Rodovia, BR-465, Km 7 (antiga Rodovia Rio/São Paulo), Bairro Ecologia, CEP 23891-000, Seropédica, RJ, Brasil

${ }^{d}$ Embrapa Semiárido, BR 428, Km 152, CEP 56302-970, Petrolina, PE, Brasil

${ }^{e}$ Ciências Biológicas, Laboratório de Ecologia, Campus do Pantanal, Universidade Federal de Mato Grosso do Sul UFMS, Av. Rio Branco, 1.270, Bairro Universitário, CEP 79304-902, Corumbá, MS, Brasil

${ }^{\text {f} C i e ̂ n c i a s ~ B i o l o ́ g i c a s, ~ L a b o r a t o ́ r i o ~ d e ~ G e n e ́ t i c a, ~ C a m p u s ~ d o ~ P a n t a n a l, ~ U n i v e r s i d a d e ~ F e d e r a l ~ d e ~ M a t o ~ G r o s s o ~ d o ~ S u l ~-~}$ UFMS, Av. Rio Branco, 1.270, Bairro Universitário, CEP 79304-902, Corumbá, MS, Brasil

*e-mail: marivaine@hotmail.com

Received: June 25, 2019 - Accepted: November 5, 2019 - Distributed: November 30, 2020

(With 1 figure)

\begin{abstract}
Studies on the bacterial diversity associated with wild plants are rare, especially on those that grow in association with bromeliads. In the present study, we isolated and identified epiphytic and endophytic bacteria from the roots of the bromeliads Dyckia excelsa, Dyckia leptostachya and Deuterocohnia meziana occurring in the "cangas" in the Pantanal from Mato Grosso do Sul State, Brazil. The epiphytic bacteria were isolated from washed roots, while the endophytic bacteria were isolated from surface disinfested roots. Bacterial representatives corresponding to each BOX-PCR fingerprint, as well as those that did not result in amplicons, were selected for 16S rDNA gene sequence analysis. The BOX-PCR data showed intrageneric and intraspecific diversity and could discriminate strains and identify their phenotypic characteristics. The 16S rDNA gene sequence and phylogeny analysis showed a higher occurrence of strains belonging to the genus Bacillus than Mycobacterium and Brevibacterium, which were found in lower numbers. Species from the Bacillus genus are well known for their sporulation capacity and longer survival in arid locations, such as the "cangas". This study clearly showed that the bromeliad species represent a vast reservoir of bacterial community diversity, and the cultivable strains represent a new source for biotechnological prospecting.
\end{abstract}

Keywords: Bacillus, Deuterocohnia, Dyckia, endophytic, epiphytic.

\section{Diversidade de bactérias cultiváveis associadas a raízes de bromélias de afloramentos ferruginosos do Brasil central}

\begin{abstract}
Resumo
Estudos sobre a diversidade bacteriana associada a plantas silvestres são raros, especialmente naqueles que crescem em associação com bromélias. No presente estudo, isolamos e identificamos bactérias epífitas e endofíticas das raízes das bromélias Dyckia excelsa, D. leptostachya e Deuterocohnia meziana ocorrentes nas "cangas" no Pantanal do Mato Grosso do Sul, Brasil. As bactérias epifíticas foram isoladas de raízes lavadas, enquanto as bactérias endofíticas foram isoladas de raízes desinfestadas na superfície. Representantes bacterianos correspondentes a cada perfil do BOX-PCR, bem como aqueles que não resultaram em amplificações, foram selecionados para o sequenciamento do gene 16S rDNA. Os dados da BOX-PCR mostraram diversidade intragênica e intraespecífica e puderam discriminar cepas e identificar suas características fenotípicas. A seqüência do gene $16 \mathrm{~S}$ rDNA e a análise filogenética mostraram uma maior ocorrência de cepas pertencentes ao gênero Bacillus do que as bactérias Mycobacterium e Brevibacterium, encontradas em menor número. Espécies do gênero Bacillus são bem conhecidas por sua capacidade de esporulação e maior sobrevida em locais áridos, como as "cangas". Este estudo mostrou claramente que as espécies de bromélias representam um vasto reservatório de diversidade de comunidades bacterianas, e as linhagens cultiváveis podem representar uma nova fonte para a prospecção biotecnológica.
\end{abstract}

Palavras-chave: Bacillus, Deuterocohnia, Dyckia, endofíticas, epifíticas. 


\section{Introduction}

The ironstone outcrop vegetation, designated ferruginous fields, is adapted to conditions of high insolation levels, great thermal amplitude, and soil absence and periods of water scarcity, in addition to winds and floods (Takahasi and Meirelles, 2014).

The establishment of a plant species within an ecosystem often involves the association and interaction with other organisms, such as the mutualistic relationship with mycorrhizal fungi, and nitrogen-fixing bacteria (Peixoto Neto et al., 2002). The plant associative microorganisms can be established epiphytically on plant structural surfaces or endophytically within the tissues without causing damage to the plant (Sikora et al., 2007).

There are many benefits of plant-microorganism association, such as the production of plant growth hormones, induction of resistance to pathogens, pest biocontrol and nutrient availability for the plants. Alternatively, the microorganisms can benefit from the carbon compounds exuded by the roots, and in the case of endophytes, protection against predators (Compant et al., 2010).

The knowledge about bacterial species that are part of the plant-associated bacterial community is important to understand how biological processes related to plants are influenced by environmental factors. These aspects corroborate the concept that the soils of natural environments demonstrate a higher microbial diversity balance when compared to the soils from cultivated areas (Compant et al., 2010).

Few studies on bacterial/plant relationships in native bromeliads have been reported in Brazil. Only one study was conducted in the Atlantic Forest areas with the isolation and identification of bacteria from Vriesea gigantea Gaudchi. and Tillandsia aeranthos (Loiseleur) L.B. Smith (Ambrosini et al., 2007; Giongo et al., 2013). Giongo et al. (2013) isolated bacteria from water tanks and the leaf surfaces of $V$. gigantea and endophytic and phyllosphere bacteria from $T$. aeranthos. The authors obtained 68 bacterial isolates that demonstrated high morphological, physiological, and genetic diversity also demonstrated the functional characteristics of plant growth promotion. Their study demonstrated the ability of these microorganisms to survive and facilitate the establishment of plant species in nutrient-limited environments, highlighting their ecological role in different habitats. To our knowledge, no other study on the diversity and investigation of the plant growth-promoting characteristics of native Brazilian bromeliad-associated bacteria has been published.

Considering the lack of knowledge and the importance of understanding the bromeliad-microorganism association in the ironstone outcrops, this study was conducted with the goal to isolate, characterize and identify endophytic and epiphytic bacteria associated with three xerophytic bromeliad (Pitcairnioideae) species that occur in the ironstone outcrops of the Urucum Residual Plateau, Corumbá city, and Mato Grosso do Sul State, Brazil: Dyckia excelsa Leme, Dyckia leptostachya Baker and Deuterocohnia meziana Kuntze ex Mez. The following hypotheses were tested: 1) Bromeliad species have an associative capacity with bacteria; 2) Different bromeliad species lead to different types of associated cultivable bacterial diversity, and 3) Differences in soil composition can influence the cultivable bacterial diversity on the roots of bromeliads.

\section{Material and Methods}

\subsection{Bromeliaceae species and locations of occurrence}

The study was conducted in ironstone outcrops that are located at the Urucum Residual Plateau, Corumbá, Mato Grosso do Sul state (MS), Brazil. The climate of the region is classified as Awa by the Köppen system, with a dry winter and summer rains (Soriano, 2000). The mean annual precipitation of Corumbá is $1.070 \mathrm{~mm}$, and the annual average temperature is $25^{\circ} \mathrm{C}$ and ranges from 21.4 to $27.7^{\circ} \mathrm{C}$ (Soriano, 2000).

The vascular plants of this environment can form clumps and soil islands, in which the microclimatic conditions are mitigated, resulting in increased organic matter, litter, and sediment (Carmo and Kamino, 2015). Species of Bromeliaceae, such as Dyckia excelsa Leme, D. leptostachya Baker, and Deuterocohnia meziana Kuntze ex Mez., occur on rocky outcrops in the city of Corumbá and Ladário (MS), forming groups in soil islands in most cases (Pott and Pott, 1994; Paggi et al., 2015).

\subsection{Plant sampling}

Plant material was collected from the Urucum Residual Plateau at three different ironstone outcrops: São João Farm (SJF) (19 $10^{\prime} 45.53$ ' S and 57 32'17.67” W); Piraputangas Municipality Park (PMP) (19¹4’37.27’' S and 57 $38^{\prime} 15.09^{\prime \prime} \mathrm{W}$ ) and Lajedo Archeological Site (LAS) $\left(19^{\circ} 14^{\prime} 11.41^{\prime \prime} \mathrm{S}\right.$ and $\left.57^{\circ} 38^{\prime} 44.81^{\prime \prime} \mathrm{W}\right)$. Three individuals of D. excelsa (DE) were collected at the SJF, nine individuals of $D$. leptostachya (DL) at the three areas and six individuals of Deuterocohnia meziana (DM) at two areas (PMP and LAS). Due to the absence of some plant species in the three ironstone areas, it was not possible to sample all the species in the three sites. These species occur in specific areas of soils, designated "soil islands" or "vegetation islands" in the ironstone outcrops. Therefore, individual plants from islands with different sizes were obtained.

\subsection{Soil characteristics}

Soil samples were collected from each bromeliad island and analyzed for chemical properties $(\mathrm{pH}$, phosphorus, iron and organic matter) followed the Mehlich method (Mehlich, 1953) and physical properties, such as particle size analysis, using the pipette method (EMBRAPA, 1997).

\subsection{Isolation of bacteria associated with the roots of bromeliads}

The bacterial counting and isolation used the protocol described by Kuklinsky-Sobral et al. (2004) with some modifications; it was used in the medium TSA $4 \%$ supplemented with $50 \mu \mathrm{g} \mathrm{mL}^{-1}$ of the Cercobin 
fungicide $(700 \mathrm{Wp})$ rather than TSA $10 \%$ supplemented with $50 \mu \mathrm{g} \mathrm{mL}^{-1}$ of Imazil. The endophytic bacteria were isolated after removing the epiphytic population (described above) (Kuklinsky-Sobral et al., 2004).

\subsection{Morphological characteristics and $B O X-P C R$}

The following morphological characteristics of the colonies were evaluated: size $(\mathrm{mm})$, border (regular or irregular), color, shape (circular or irregular), rise (flat or convex) and shine (with or without) according to the Bergey's Manual ${ }^{\circledR}$ of Systematic Bacteriology (Garrity et al., 2004). Bacteria with the same morphological characteristics were grouped for future taxonomic analysis.

Isolates representative from each morphological groups were randomly sampled for BOX-PCR analysis. The bacterial isolates were grown on plates containing TSA media for three days, and purified bacterial isolates were resuspended in $100 \mu \mathrm{l}$ of MilliQ water and mixed in a vortex. One $\mu \mathrm{l}$ of cell suspension was used for PCR (polymerase chain reaction) amplification of the BOX-A region. The primer Box-A1R (5'CTACGGCAAGGCGACGCTGACG3') and BOX-PCR conditions were as described by Versalovic et al. (1994). The amplification products were subjected to horizontal electrophoresis in a $1 \%(\mathrm{w} / \mathrm{v})$ agarose gel at $100 \mathrm{~V}$ for four hours. The BOX-PCR profiles were analyzed using the software BioNumerics v 7.1 (Applied Maths, Belgium).

\section{6. $16 \mathrm{~S}$ rDNA gene sequence analysis}

Representative bacterial strains from each different morphological group were selected to sequence the 16S rDNA gene. DNA extraction was conducted using a Wizard ${ }^{\circledR}$ Genomic DNA Purification Kit (Promega) using the manufacturer's instructions. The primers $27 \mathrm{~F}$ (5'AGAGTTTGATCCTGGCTCAG3') (Furushita et al., 2003) and Amp2 (3'AAGGAGGTGATCCARCCGCA5') (Wang et al., 1993) were used to amplify the $16 \mathrm{~S}$ rDNA gene, generating an amplicon of approximately $1400 \mathrm{bp}$. The PCR products were precipitated using ammonium acetate $7 \mathrm{M}\left(\mathrm{NH}_{4} \mathrm{Ac}\right)$ and absolute ethanol and sequenced at the Macrogen Company, South Korea. The sequences were analyzed against the BLASTn software - NCBI database. All sequences were deposited in GenBank (access numbers MG027622 to MG027688). For the phylogenetic tree construction, the sequences were aligned using the Clustal W software (Thompson et al., 1994), and the tree was constructed based on the comparison of the sequences using the neighbor-joining method (Saitou and Nei, 1987). The evolutionary distance was computed using the Kimura 2-parameter method (Kimura, 1980) with a bootstrap of 1000 repetitions, and the phylogenetic analysis was conducted using the MEGA6 software (Tamura et al., 2013).

\subsection{Diversity of bacterial strains and correlation with bromeliad islands and soil characteristics}

The analysis of the bacterial diversity related to the plant species was conducted by considering the number of bacterial species occurring in each plant species divided by the total number of bacterial species that were identified using the $16 \mathrm{~S}$ rDNA gene sequencing. The bacterial diversity was estimated using the Shannon-Wiener diversity index (Bowman et al., 1971). The dominance and equitability of the bacterial isolates were calculated using the Simpson and Equitability-J indices. The pairwise comparison of the indices for the paired bromeliad species within the same area was conducted using the permutation tests. The ecological indices calculations and analyses were conducted using the PaSt software v 2.17 (Hammer et al., 2001). Pearson's correlations were determined using the BioEstat 5.0 software, (Ayres et al., 2007) and the correlations between bacterial diversity and bromeliad island size and between bacteria diversity and soil physicochemical characteristics were determined.

\section{Results}

\subsection{Epiphytic and endophytic bacterial population colonizing bromeliad species and their morphotypes}

The estimated number of epiphytic and endophytic bacteria detected by the most probable number (MPN) in D. leptostachya grown in the São João farm was $2.6 \times 10^{6}$ and $3.0 \times 10^{6} \mathrm{CFU} / \mathrm{g}$ of fresh roots, respectively (Table 1). D. excelsa grown in the same area was found to harbor an epiphytic bacterial population of $420 \times 10^{6}$, while endophytic bacterial counting indicated that there were $8.4 \times 10^{6} \mathrm{CFU} / \mathrm{g}$ fresh roots. For D. leptostachya growing in the Piraputangas Municipality Park, the epiphytic bacterial population was $14.5 \times 10^{6}$, while the endophytic bacteria were $4.0 \times 10^{6} \mathrm{CFU} / \mathrm{g}$ fresh roots. No endophytic bacteria were detected from D. meziana in the Piraputangas Municipality Park. However, the number of epiphytic bacteria was $0.10 \times 10^{6} \mathrm{CFU} / \mathrm{g}$ fresh roots. At the Lajedo Archeological Site, the bacterial counts associated with D. leptostachya were $390 \times 10^{6}$ and $8.0 \times 10^{6} \mathrm{CFU} / \mathrm{g}$ fresh roots for epiphytic and endophytic bacteria, respectively. The numbers of epiphytic bacteria from $D$. meziana were $0.8 \times 10^{6}$, while the endophytic bacteria were $99 \times 10^{6} \mathrm{CFU} / \mathrm{g}$ fresh roots (Table 1).

A total of 71 epiphytic strains and 38 endophytic strains were isolated, and many had different morphological colony characteristics (Table S1). Out of the 71 epiphytic bacteria, 28 were isolated from $D$. leptostachya, 29 from $D$. meziana and 14 from $D$. excelsa. Among the 38 endophytic bacteria, 22 were isolated from $D$. leptostachya, 14 from $D$. meziana and two from $D$. excelsa (Table S1). The bacterial characterization based on the colony morphology demonstrated very high phenotypic diversity. The formation of 12 groups can be observed with four of them containing only one isolate (Table S1). Group C demonstrated the highest number of strains with colonies showing characteristics such as cream (color), filamentous, plans, filamentous edges, and shiny.

\subsection{BOX-PCR and 16S rDNA taxonomical analysis}

Out of the 67 bacterial sequences evaluated, 21 originated from different fingerprints generated by the BOX-PCR, and 44 from those bacteria that did not show BOX-PCR amplified products but demonstrated different morphological features (Figure 1; Table S2-supplementary 
material; Figure S1-supplementary material). Most of the strains sequenced $(67.7 \%)$ were highly similar to the genus Bacillus with $99 \%$ similarity. From those, $61.4 \%$ were phylogenetically similar to the species $B$. cereus, $6.8 \%$ to B. subtilis, $4.5 \%$ to $B$. safensis, $2.3 \%$ to $B$. aerius and $2.3 \%$ to $B$. thurigiensis. The analysis of the remaining sequences indicated that $22.7 \%$ were similar to Alcaligenes faecalis with $99 \%$ similarity, followed by the genus Lysinibacillus in which $16 \%$ of the strains resembled the genus and to the L. sphaericus species with $99 \%$ similarity. Paenibacillus was represented by $6.8 \%$ of the total strains, with $99 \%$ similarity to the species P. lautus and P. illionensis. In addition, Proteus constituted $6.8 \%$ of the sequences, represented by $P$. terrae and $P$. vulgaris. The other genera comprised 2 to $5 \%$ of the strains analyzed (Figure 1; Tables S1 and S2-supplementary material).

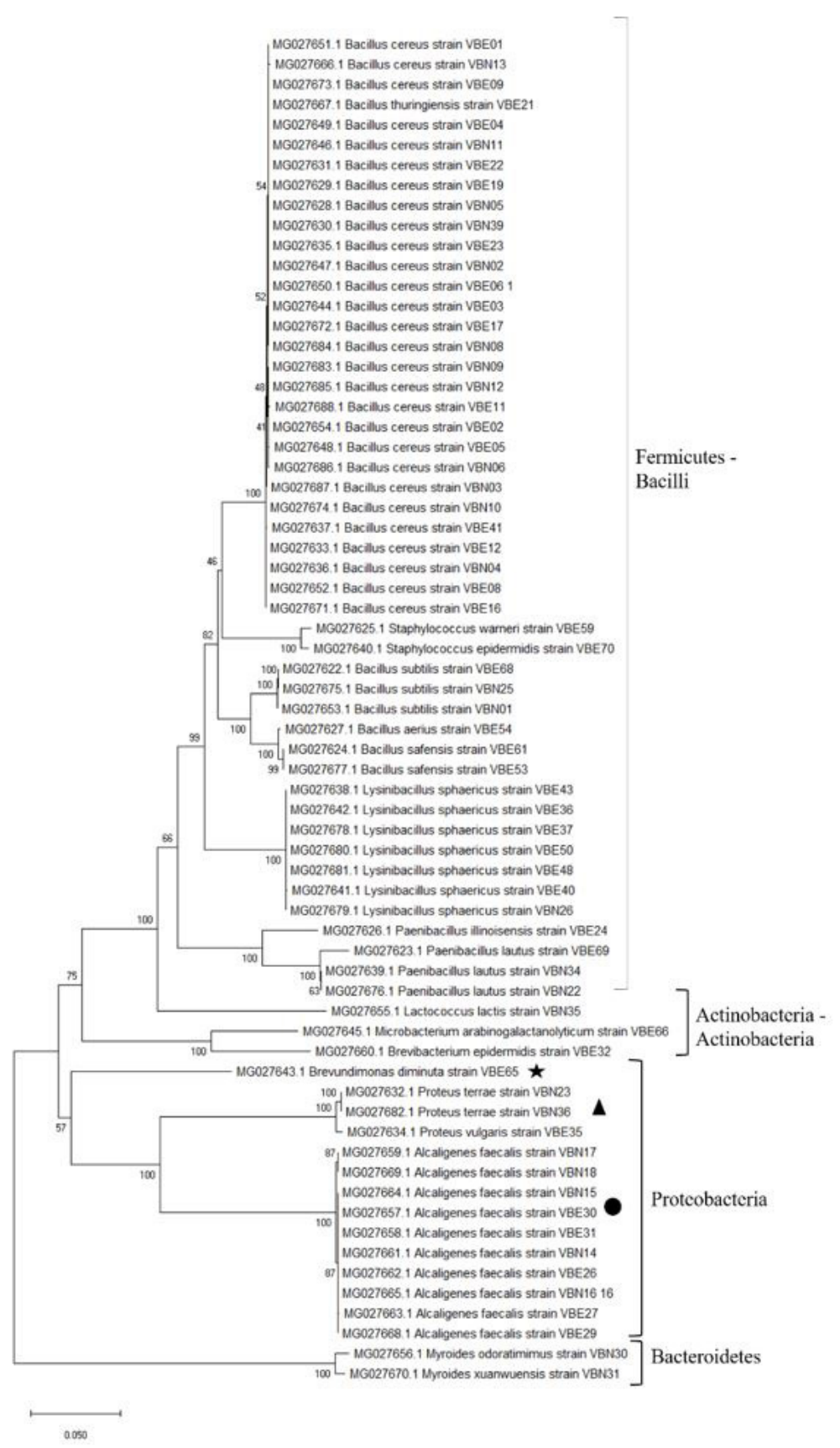

Figure 1. Phylogenetic relationships among bacterial isolates from bromeliad roots based on the partial 16S rDNA sequences. The numbers above each branch indicate bootstrap values of distance. The reliability of the neighbour-joining tree was estimated by bootstrap analysis with 1000 pseudoreplicate data sets. Classes: ^ Alphaproteobacteria; $\Delta$ Gammaproteobacteria; • Betaproteobacteria. 
The phyla analysis indicated that Firmicutes was the most representative phylum with 49 bacteria belonging to the bacilli class: B. thurigiensis, B. cereus, B. subtilis, B. safensis, Staphylococcus epidermidis, and Lysinibacillus sphaericus. The second most representative phylum was the Proteobacteria with 14 strains, distributed in three classes: ß-Proteobacteria containing 10 strains identified as Alcaligenes faecalis, $\gamma$-Proteobacteria comprising 3 strains identified as Proteus terrae and P. vulgaris (Figure 1), and the $\alpha$-Proteobacteria with one isolate belonging to Brevudimonas diminuta. Two other phyla appeared that are less well represented: Actinobacteria (Microbacterium arabinogalactanolyticum and Brevibacterium epidermidis) and Bacteroidetes with two strains belonging to Myroides odoratimimus and Myroides xuanwuensis (Figure 1). Although the phylogenetic tree showed a relationship between the species $B$. thuringiensis and $B$. cereus, and among $B$. subtilis and $B$. safensis, the other species from the Firmicutes phylum formed separate groups, despite the short distance between them (Figure 1).

\subsection{Bacterial diversity index}

The three bromeliad species showed different numbers of bacterial species associated with their roots (Figure S2-supplementary material). Higher numbers of bacteria were associated with $D$. leptostachya than with the other two species of bromeliads. The results showed significant differences $(p<0.05)$ in the Shannon-Wiener and Simpson indices when the $16 \mathrm{~S}$ rDNA diversity of the bacteria isolated from D. leptostachya and D. meziana in the Lajedo Archeological Park was compared (Table 2). The Equitability-J in the three sites evaluated and the Shannon-Wiener and Simpson indices at the Piraputanga and São João Farm indicated a lack of significant differences among the bacterial isolates associated with the bromeliads. The correlation between bacterial diversity with all the parameters (organic material, phosphorous, macronutrients, CTC, $\mathrm{pH}$, sand, silt, clay, and vegetation index) was not statistically significant (Table 3).

Table 1. Colony-forming units (CFU) of epiphytic and endophytic bacteria $\left(\mathrm{x} 10^{6}\right)$ in different populations of bromeliads and total number of bacterial isolates for each bromeliad species.

\begin{tabular}{|c|c|c|c|c|c|}
\hline \multirow{2}{*}{ Bromeliad species } & \multicolumn{3}{|c|}{$\mathrm{CFU} / \mathrm{g}$ fresh root } & \multicolumn{2}{|c|}{ Total of bacteria } \\
\hline & LAS & PMP & SJF & Epiphytic & Endophytic \\
\hline Dyckia excelsa & - & - & $8.4 / 420$ & 14 & 2 \\
\hline Dyckia leptostachya & $390 / 8.0$ & $14.5 / 4.0$ & $2.6 / 3.0$ & 28 & 22 \\
\hline Deuterocohnia meziana & $0.8 / 99$ & $0.1 / \mathrm{nd}^{*}$ & - & 29 & 14 \\
\hline Total & & & & 71 & 38 \\
\hline
\end{tabular}

LAS - Lajedo Archeological Site; PMP - Piraputangas Municipality Park; SJF - São João Farm; *=below the minimum number of cells detected by this technique.

Table 2. Bacteria diversity index comparing bacteria genera and isolates diversity, based on the 16s rDNA sequence, for all bromeliad species from each location.

\begin{tabular}{|c|c|c|c|c|}
\hline Index & D. leptostachya & D. meziana & D. excelsa & $p$ \\
\hline \multicolumn{5}{|c|}{ LAS } \\
\hline Genera (n) & 10 & 4 & & \\
\hline Isolates (n) & 23 & 17 & & \\
\hline Shannon & 2.08 & 1.19 & & 0.0057 \\
\hline Simpson & 0.84 & 0.66 & & 0.0337 \\
\hline Equitability-J & 0.90 & 0.86 & & 0.6084 \\
\hline \multicolumn{5}{|c|}{ PMP } \\
\hline Genera (n) & 3 & 3 & & \\
\hline Isolates (n) & 7 & 13 & & \\
\hline Shannon & 0.96 & 0.93 & & 1 \\
\hline Simpson & 0.57 & 0.54 & & 0.8474 \\
\hline Equitability-J & 0.87 & 0.84 & & 0.9397 \\
\hline \multicolumn{5}{|c|}{ SJF } \\
\hline Genera (n) & 4 & & 5 & \\
\hline Isolates (n) & 14 & & 15 & \\
\hline Shannon & 0.90 & & 1.44 & 0.1569 \\
\hline Simpson & 0.46 & & 0.73 & 0.1102 \\
\hline Equitability-J & 0.65 & & 0.89 & 0.0913 \\
\hline
\end{tabular}

LAS - Lajedo Archeological Site; PMP - Piraputangas Municipality Park; SJF - São João Farm. 
Table 3. Chemical and physical properties of the soils under the bromeliads species collected in different localities and used in this study. Units: $\mathrm{OM}\left(\mathrm{g} \mathrm{dm}^{-3}\right), \mathrm{P}\left(\mathrm{mg} \mathrm{mL}^{-1}\right), \mathrm{K}\left(\mathrm{cmol}_{\mathrm{c}} \mathrm{dm}^{-3}\right), \mathrm{Ca}\left(\mathrm{cmol}_{\mathrm{c}} \mathrm{dm}^{-3}\right), \mathrm{Mg}\left(\mathrm{cmol}_{\mathrm{c}} \mathrm{dm}^{-3}\right), \mathrm{Al}\left(\mathrm{cmol}_{\mathrm{c}} \mathrm{dm}^{-3}\right)$, CTC $\left(\mathrm{cmol}_{\mathrm{c}} \mathrm{dm}^{-3}\right)$, Clay (\%), Silt (\%), Sand (\%) and $\mathrm{pH}$.

\begin{tabular}{|c|c|c|c|c|c|c|c|c|c|c|c|c|}
\hline \multirow{2}{*}{$\begin{array}{c}\text { Bromeliads } \\
\text { species }\end{array}$} & \multicolumn{12}{|c|}{ Chemical and physical soil characteristics } \\
\hline & Locality & OM$^{1}$ & $\mathbf{P}^{2}$ & $\mathbf{K}^{3}$ & $\mathrm{Ca}^{4}$ & $\mathrm{Mg}^{5}$ & $\mathbf{A l}^{6}$ & $\mathrm{CTC}^{7}$ & Clay $^{8}$ & Silt $^{9}$ & Sand $^{10}$ & $\mathbf{p H}^{11}$ \\
\hline D. excelsa & São João Farm & 73.3 & 14 & 3.7 & 138 & 33 & 1 & 206.3 & 11.2 & 39.6 & 49.2 & 6.6 \\
\hline D. leptostachya & São João Farm & 127.8 & 34.6 & 5.2 & 228.6 & 44.3 & 1 & 306 & 11.6 & 54 & 34.3 & 6.5 \\
\hline D. leptostachya & $\begin{array}{l}\text { Piraputangas } \\
\text { Municipality Park }\end{array}$ & 75 & 15 & 3.1 & 18.6 & 5 & 14 & 124 & 15.1 & 26.8 & 58 & 4.8 \\
\hline D. meziana & $\begin{array}{l}\text { Piraputangas } \\
\text { Municipality Park }\end{array}$ & 105.9 & 20 & 3.4 & 38.6 & 5 & 10.6 & 143.6 & 9 & 31.1 & 59.9 & 5.0 \\
\hline D. leptostachya & $\begin{array}{l}\text { Lajedo } \\
\text { Archeological Site }\end{array}$ & 46.8 & 14.3 & 2.5 & 15 & 3.3 & 14.6 & 106.3 & 11.4 & 15 & 57 & 4.8 \\
\hline D. meziana & $\begin{array}{l}\text { Lajedo } \\
\text { Archeological Site }\end{array}$ & 63.2 & 30.3 & 3.6 & 50.3 & 8.6 & 3.6 & 131.6 & 12.8 & 25.6 & 61.6 & 5.0 \\
\hline
\end{tabular}

\section{Discussion}

The numbers of bacteria founded were similar to those detected in monocotyledonous plants, in which $10^{5}$ to $10^{7}$ bacteria $\mathrm{g}^{-1}$ fresh plant tissue was observed either in the rhizosphere or inside of the plant tissues (Baldani et al., 2014). The higher bacterial population observed in the plant roots than soil reflects the presence of greater amount of nutrients in the rhizosphere and rhizoplane than in the leaves, assuming that these nutrients are responsible for the increased amount of bacterial growth and development (Giongo et al., 2013).

In general, endophytic bacteria occur at lower population densities than rhizospheric bacteria (Rosenblueth and Martínez-Romero, 2006). Younger plants have higher bacterial populations than mature ones, and the numbers of epiphytic bacteria are usually higher than that of endophytic bacteria (James et al., 2002). However, it is not clear whether the plants benefit more from an endophyte than from a rhizospheric bacterium or if it is more advantageous for the bacteria to become endophytic and to colonize inside of the plant tissues (Rosenblueth and Martínez-Romero, 2006).

The morphology of the analyzed colonies showed high diversity, despite the use of only one culture medium for counting and isolation. The morphological characteristics of microorganisms in pure culture are required for a detailed analysis of their genetics and physiological aspects (Turner et al., 2013), in addition to serving as the first step for microbial diversity study, as well as to assure the purity of the colonies and culture storage. The BOX-PCR fingerprint and the $16 \mathrm{~S}$ rDNA sequencing data showed that the diversity of epiphytic and endophytic bacteria was higher than that observed from the morphological analysis. Different subgroups were observed in the dendrogram, with only three subgroups closely related. However, the cluster analysis did not indicate the effect of the plant tissues or the plant genotype on bacterial diversity.

We observed the presence of Bacillus cereus and B. thuringiensis within the same cluster at the phylogenetic tree, consistent with reports by Ohba (2011) and Liu et al. (2015) that $B$. thuringiensis is allocated into the Bacillus cereus group together with the two other species, Bacillus anthracis and Bacillus mycoides. Bacillus species are known to form aerobic spores and survive in arid regions, which comprise a range of soil depths, altitudes, and other climatic conditions (Rettedal and Brozel, 2015). The bromeliad species from which the strains were isolated occur in a dry environment exposed to high thermal amplitudes and dehydration, the ironstone outcrops, which could favor the presence of Bacillus species instead of other bacterial species. Some studies described the isolation of Bacillus species from arid regions. The habitat features that are determinant to isolate Bacillus due to the specific climate of the study area are similar to those reported previously. Fernandes-Júnior et al. (2015) studied the bacterial community in Caatinga grasses and observed the presence of the Bacillus genus. Chávez-Ambriz et al. (2016), also observed the occurrence of Bacillus in the cacti rhizosphere of the arid zones in Mexico where rainfall is scarce, evapotranspiration is high and soil fertility low.

Bacillus cereus was the most frequent species detected in this study is widely reported to be a soil bacterium and a food poisoning bacterium that can occasionally be an opportunistic human pathogen (Schoeni and Wong, 2005). The 16S rDNA gene sequences also showed the occurrence of a considerable number of strains identified as Alcaligenes faecalis. This species can produce plant growth hormones, as well as ACC deaminase (Sgroy et al., 2009).

Higher bacterial diversity was observed associated with D. excelsa without the presence of Bacillus cereus different from the observations for D. leptostachya grown in the same area (Table 2). High numbers of $B$. cereus strains were also observed associated with $D$. meziana. The sampling effort may have influenced these results; it has been demonstrated that increases in sampling attempts result in the capture of greater diversity (Lyngwi et al., 2013). The bacterial diversity can be influenced by microbiota mixing, transportation by soil fauna, and the stability 
of communities in biofilms at the interface between the roots and soil.

In conclusion, this study demonstrates that different bromeliad species may influence the bacterial diversity as observed for Lajedo Archeological Site, where there are differences in bacterial diversity between D. meziana and D. leptostachya. Differences among the ecological indices were only observed when different bromeliad species were compared in the LAS. Moreover, in our study, there were no correlations among soil characteristics, and bacterial diversity in all the locations studied.

\section{Acknowledgements}

This study was funded by FUNDECT (Fundação de Apoio ao Desenvolvimento do Ensino, Ciência e Tecnologia do Estado de Mato Grosso do Sul -Chamada Edital FUNDECT/CNPq n ${ }^{\circ}$ 06/2006 PPP), and by the National Council for Scientific and Technologic Development (CNPq - Edital Universal 14/2013).

\section{References}

AMBROSINI, A., GIONGO, A., BENEDUZI, A., COBALCHINI, N., FRIEDRICH, L. and PASSAGLIA, L.M.P., 2007. Bactérias promotoras de crescimento vegetal em Vriesea gigantea Gaudchi. (Bromeliaceae). Revista Brasileira de Biociências, vol. 5, no. 2, pp. 1169-1170.

AYRES, M., AYRES JUNIOR, M., AYRES, D.L. and SANTOS, A.S., 2007. Bioestat 5.0 - aplicações estatísticas nas áreas das ciências biomédicas. Belém: ONG Mamirauá.

BALDANI, J.I., REIS, V.M., VIDEIRA, S.S., BODDEY, L.H. and BALDANI, V.L.D., 2014. The art of isolating nitrogen-fixing bacteria from non-leguminous plants using $\mathrm{N}$-free semi-solid media: a practical guide for microbiologists. Plant and Soil, vol. 384, no. 1-2, pp. 413-431. http://dx.doi.org/10.1007/s11104-014-2186-6.

BOWMAN, K.O., HUTCHESON, K., ODUM, E.P. and SHENTON, L.R., 1971. Comments on the distribution of indices of diversity. In G.P. Patil, E.C. Pielou, and W.E. Walters, eds. Statistical ecology. Many species populations, ecosystems, and systems analysis (pp. 315-366). Pennsylvania: University Park.

CARMO, F.F. and KAMINO, L.H.Y., 2015. Geossistemas Ferruginosos do Brasil: áreas prioritárias para conservação da diversidade geológica e biológica, patrimônio cultural e serviços ambientais. Belo Horizonte: Editora 3i Ltda.

CHÁVEZ-AMBRIZ, L.A., HERNÁNDEZ-MORALES, A., CABRERA-LUNA, J.A., LUNA-MARTÍNEZ, L. and PACHECO-AGUILAR, J.R., 2016. Aislados de Bacillus provenientes de la rizósfera de cactus incrementan la germinación y la floración en Mammillaria spp. (Cactaceae). Revista Argentina de Microbiologia, vol. 48, no. 4, pp. 333-341. http://dx.doi. org/10.1016/j.ram.2016.09.001. PMid:27876169.

COMPANT, S., CLEMENT, C. and SESSITSCH, A., 2010. Plant growth-promoting bacteria in the rhizo- and endosphere of plants: their role, colonization, mechanisms involved and prospects for utilization. Soil Biology \& Biochemistry, vol. 42, no. 5, pp. 669-678. http://dx.doi.org/10.1016/j.soilbio.2009.11.024.

EMPRESA BRASILEIRA DE PESQUISA AGROPECUÁRIA CENTRO NACIONAL DE PESQUISA DE SOLOS - EMBRAPA,
1997. Manual de métodos de análise de solo. 2nd ed. Rio de Janeiro: EMBRAPA. 212 p.

FERNANDES-JÚNIOR, P.I., AIDAR, S.T., MORGANTE, C.V., GAVA, C.A.T., ZILLI, J.É., SOUZA, L.S.B., MARINHO, R.C.N., NÓBREGA, R.S.A., BRASIL, M.S., SEIDO, S.L. and MARTINS, L.M.V., 2015. The resurrection plant Tripogon spicatus (Poaceae) harbors a diversity of plant growth promoting bacteria in northeastern brazilian Caatinga. Revista Brasileira de Ciência do Solo, vol. 39, no. 4, pp. 993-1002. http://dx.doi.org/1 0.1590/01000683rbcs20140646.

FURUSHITA, M., SHIBA, T., MAEDA, T., YAHATA, M., KANEOKA, A., TAKAHASHI, Y., TORII, K., HASEGAWA, T. and OHTA, M., 2003. Similarity of tetracycline resistance genes isolated from fish farm bacteria to those from clinical isolates. Applied and Environmental Microbiology, vol. 69, no. 9, pp. 5336-5342. http://dx.doi.org/10.1128/AEM.69.9.53365342.2003. PMid:12957921.

GARRITY, G.M., BELL, J.A. and LILBURN, T.G., 2004. Taxonomic outline of the prokaryotes Bergey's manual ${ }^{\circledR}$ of systematic bacteriology. New York: Springer.

GIONGO, A., BENEDUZI, A., GANO, K., VARGAS, L.K., UTZ, L. and PASSAGLIA, L.M.P., 2013. Characterization of plant growth-promoting bacteria inhabiting Vriesea gigantea Gaud. and Tillandsia aeranthos (Loiseleur) L B Smith (Bromeliaceae). Biota Neotropica, vol. 3, no. 3, pp. 80-85. http://dx.doi.org/10.1590/ S1676-06032013000300010.

HAMMER, O., HARPER, D.A.T. and RYAN, P.D., 2001. PAST: paleontological statistics software package for education and data analysis. Palaeontologia Electronica, vol. 4, no. 1, pp. 9.

JAMES, E.K., GYANESHWAR, P., MATHAN, N., BARRAQUIO, Q.L., REDDY, P.M., IANNETTA, P.P.M., OLIVARES, F.L. and LADHA, J.K., 2002. Infection and colonization of rice seedlings by the plant growth-promoting bacterium Herbaspirillum seropedicae Z67. Molecular Plant-Microbe Interactions Journal, vol. 15, no. 9, pp. 894-906. http://dx.doi.org/10.1094/MPMI.2002.15.9.894. PMid:12236596.

KIMURA, M., 1980. A simple method for estimating evolutionary rates of base substitutions through comparative studies of nucleotide sequences. Journal of Molecular Evolution, vol. 16, no. 2, pp. 111-120. http://dx.doi.org/10.1007/BF01731581. PMid:7463489.

KUKLINSKY-SOBRAL, J., ARAÚJO, W.L., MENDES, R., GERALDI, I.O., PIZZIRANI-KLEINER, A.A. and AZEVEDO, J.L., 2004. Isolation and characterization of soybean-associated bacteria and their potential for plant growth promotion. Environmental Microbiology, vol. 6, no. 12, pp. 1244-1251. http:// dx.doi.org/10.1111/j.1462-2920.2004.00658.x. PMid:15560822.

LIU, Y., LAI, Q., GÖKER, M., MEIER-KOLTHOFF, J.P., WANG, M., SUN, Y., WANG, L. and SHAO, Z., 2015. Genomic insights into the taxonomic status of the Bacillus cereus group. Scientific Reports, vol. 5, no. 1, pp. 14082. http://dx.doi.org/10.1038/ srep14082. PMid:26373441.

LYNGWI, N.A., KOIJAM, K., SHARMA, D. and JOSHI, S.R., 2013. Cultivable bacterial diversity along the altitudinal zonation and vegetation range of tropical Eastern Himalaya. Revista de Biología Tropical, vol. 61, no. 1, pp. 467-490. http://dx.doi. org/10.15517/rbt.v61i1.11141. PMid:23894996.

MEHLICH,A., 1953. Determination of $\mathrm{P}, \mathrm{Ca}, \mathrm{Mg}, \mathrm{K}, \mathrm{Na}$ and $\mathrm{NH}_{4}$ by North Carolina soil testing laboratories. Raleigh: University of North Carolina. 
OHBA, M., 2011. Bacillus thuringiensis diversity in soil and phylloplane. In N. LOGAN, P. VOS, eds. Endospore-forming soil bacteria. Soil biology (pp. 215-233). Berlin: Springer, vol. 27.

PAGGI, G.M., LOUZADA, R.B., ISHII, I.H., TAKAHASI, A., ARRUDA, R.O. and LORENZ-LEMKE, A.P., 2015. Rediscovering Dyckia excelsa (Bromeliaceae) in Mato Grosso do Sul, Brazil: taxonomy, geographic distribution, and notes on leaf anatomy. Systematic Botany, vol. 40, no. 1, pp. 129-135. http://dx.doi.org/10.1600/036364415X686422.

PEIXOTO NETO, P.A.S., AZEVEDO, J.L. and ARAÚJO, W.L., 2002. Microorganismos endofíticos: interação com plantas e potencial biotecnológico. Revista Biotecnologia Ciência e Desenvolvimento, vol. 29, pp. 62-76.

POTT, A. and POTT, V.J., 1994. Plantas do Pantanal. Brasília: Embrapa-SPI.

RETTEDAL, E.A. and BROZEL, V.S., 2015. Characterizing the diversity of active bacteria in soil by comprehensive stable isotope probing of DNA and RNA with $\mathrm{H}_{2}{ }^{18} \mathrm{O}$. Microbiology Open, vol. 4, no. 2, pp. 208-219. http://dx.doi.org/10.1002/mbo3.230. PMid:25650291.

ROSENBLUETH, M. and MARTÍNEZ-ROMERO, E., 2006. Bacterial endophytes and their interactions with hosts. Molecular Plant-Microbe Interactions, vol. 19, no. 8, pp. 827-837. http:// dx.doi.org/10.1094/MPMI-19-0827. PMid:16903349.

SAITOU, N. and NEI, M., 1987. The neighbor-joining method: a new method for reconstructing phylogenetic trees. Molecular Biology and Evolution, vol. 4, no. 4, pp. 406-425. PMid:3447015.

SCHOENI, J.L. and WONG, A.C., 2005. Bacillus cereus food poisoning and its toxins. Journal of Food Protection, vol. 68, no. 3, pp. 636-648. http://dx.doi.org/10.4315/0362-028X-68.3.636. PMid:15771198.

SGROY, V., CASSÁN, F., MASCIARELLI, O., DEL PAPA, M.F., LAGARES, A. and LUNA, V., 2009. Isolation and characterization of endophytic plant growth-promoting (PGPB) or stress homeostasisregulating (PSHB) bacteria associated to the halophyte Prosopis strombulifera. Applied Microbiology and Biotechnology, vol. 85, no. 2, pp. 371-381. http://dx.doi. org/10.1007/s00253-009-2116-3. PMid:19655138.

SIKORA, R.A., SCHÄFER, K. and DABABAT, A.A., 2007. Modes of action associated with microbially induced in planta suppression of plant-parasitic nematodes. Australasian Plant Pathology, vol. 36, no. 2, pp. 124-134. http://dx.doi.org/10.1071/ AP07008.

SORIANO, B.M.A. (2000). Zoneamento ambiental da borda oeste do Pantanal: maciço do Urucum e adjacências. In: J.S.V. SILVA, ed. Climatologia, Embrapa Comunicação para Transferência de Tecnologia (pp. 69-81). Brasília: EMBRAPA.

TAKAHASI, A. and MEIRELLES, S.T., 2014. Ecologia da vegetação herbácea de bancadas lateríticas (cangas) em Corumbá, MS, Brasil. Hoehnea, vol. 41, no. 4, pp. 515-528. http://dx.doi. org/10.1590/2236-8906-63/2013.

TAMURA, K., STECHER, G., PETERSON, D., FILIPSKI, A. and KUMAR, S., 2013. MEGA6: Molecular Evolutionary Genetics Analysis version 6.0. Molecular Biology and Evolution, vol. 30, no. 12, pp. 2725-2729. http://dx.doi.org/10.1093/molbev/ mst197. PMid:24132122.

THOMPSON, J.D., HIGGINS, D.G. and GIBSON, T.J., 1994. CLUSTAL W: improving the sensitivity of progressive multiple sequence alignment through sequence weighting, position-specific gap penalties and weight matrix choice. Nucleic Acids Research, vol. 22, no. 22, pp. 4673-4680. http://dx.doi.org/10.1093/ nar/22.22.4673. PMid:7984417.

TURNER, T.R., JAMES, E.K. and POOLE, P.S., 2013. The plant microbiome. Genome Biology, vol. 14, no. 6, pp. 209. http://dx.doi.org/10.1186/gb-2013-14-6-209. PMid:23805896.

VERSALOVIC, J., SCHNEIDER, M., DE BRUIJN, F.J. and LUPSKI, J.R., 1994. Genomic fingerprinting of bacteria using repetitive sequence-based polymerase chain reaction. Methods in Molecular and Cellular Biology, vol. 5, pp. 25-40.

WANG, H., QI, M. and CUTLER, A.J., 1993. A simple method of preparing plant samples for PCR. Nucleic Acids Research, vol. 21, no. 17, pp. 4153-4154. http://dx.doi.org/10.1093/nar/21.17.4153. PMid:8371994. 


\section{Supplementary Material}

Supplementary material accompanies this paper.

Figure S1. Dendrogram comparing BOX-PCR profiles among bacterial isolates of bromeliad species. The scale at the top of the figure represents percent similarity.

Figure S2. (A) Detail of a flowering individual of Dyckia excelsa, São João Farm, Corumbá, MS, also showing the substrate of the canga. (B) General view of some individuals of Dyckia excelsa, São João Farm, Corumbá, MS.

(C) Detail of the flowers of Deuterocohnia meziana, Lajedo Arqueological Site, Corumbá, MS. (D) General view

of some individuals growing clonally of Deuterocohnia meziana, Lajedo Arqueological Site, Corumbá, MS. (E) Detail of individuals of Dyckia leptostachya, Piraputangas Municipal Park, MS, also showing the substrate of the canga. (F) flowering individual of Dyckia leptostachya, Piraputangas Municipal Park, MS. Photos: GM Paggi.

Table S1. Morphological characteristics of colonies on TSA medium and their respective groups.

Table S2. Taxonomic affiliations of bacteria isolated from soils determined by $16 \mathrm{~S}$ rDNA gene sequences, showing the closest identified match in the NCBI database.

This material is available as part of the online article from http://www.scielo.br/BJB 